\title{
Doenças de feitiço as Minas setecentistas e o imaginário das doenças*
}

\section{Diseases from witchcraft}

Eighteenth century Minas Gerais captaincy/Brazil and the imaginary of the diseases *

\author{
ANDRÉ LUÍS LIMA NOGUEIRA \\ Doutorando em História das Ciências e da Saúde pela \\ Casa de Oswaldo Cruz FIOCRUZ; bolsista CAPES \\ Av. Brasil, 4036, $4^{\circ}$ andar, sala 417 \\ CEP 21040-36, Manguinhos, Rio de Janeiro, RJ \\ guazo08@gmail.com
}

\begin{abstract}
RESUMO $O$ presente artigo objetiva discutir a crença e o consenso em torno da ideia partilhada, entre aqueles que viveram nas Minas no curso do século XVIII, de que determinados indivíduos poderiam, por meio de feitiços, provocar uma série de males. Assim, as doenças de feitiço, conforme aparecem na documentação compulsada, pareciam bastante assíduas. Procurei igualmente analisar como eram descritos tais achaques provocados pelos feitiços: tolhimentos, dores, ligamentos, dentre outros. Estes se faziam presentes tanto nas denúncias levadas ao conhecimento de membros do clero no curso das devassas eclesiásticas (documentação sob a guarda do Arquivo Eclesiástico da Arquidiocese de Mariana) como em tratados médicos publicados, sobretudo, nas primeiras décadas do setecentos.
\end{abstract}

Palavras-chave feitiçaria, escravidão, doenças, Minas Gerais do século XVIII ABSTRACT This article aims to discuss the belief and the consensus around the idea shared among those who lived in Minas in the course of the ei-

\footnotetext{
* Artigo recebido em: 01/09/2010. Aprovado em: 30/11/2011.

* U Uma primeira versão deste trabalho foi apresentada no V Simpósio Escravidão e Mestiçagens: ambientes, paisagens e espaços, sob o título "Mestres insignes nessa arte": escravos e feitiços nas Minas do século XVIII. Niterói, 2010. Agradeço as sugestões de Lorelai Kury.
} 
ghteenth century that certain individuals could, by spells, cause a variety of ailments. Thus, the spell of illness, as it appears in the documentation compelling seemed very assiduous. I also tried to analyze how they were described such ailments caused by spells: stunting, pain, ligaments, among others. These were present both in the complaints brought to the attention of members of the clergy during the wanton ecclesiastical (documentation in the custody of the ecclesiastical archives of the Archdiocese of Mariana) as published in medical treatises, especially in the first decades of the $18^{\text {th }}$ century.

Keywords witchcraft, slavery, disease, Minas Gerais in the Eighteenth century.

\section{Introdução}

Em nossos dias não é incomum ouvirmos e falarmos - sem a necessidade prévia da opinião de um especialista - que uma pessoa próxima não se encontra bem de saúde em função de uma virose ou de algum tipo de infecção por bactéria. Tal diagnóstico bastante difuso, ou, se preferirmos, naturalizado, não causaria nenhuma espécie numa conversa. Entretanto, se apresentássemos como um esboço de explicação para o mesmo caso a possibilidade dessa pessoa ter sido, em verdade, vítima de feitiço, esse argumento talvez provocasse reações bem menos pacíficas.

Como historiadores, somos desafiados a pensar nas doenças, e em suas possibilidades de explicação e tratamento, não de forma dada ou naturalizada, mas como construção plural de uma determinada época e, por isso, possuidoras de especificidades que lhe são próprias, socialmente legitimadas e presentes nas crenças e práticas dos indivíduos circunscritos em dado contexto.

Nesse sentido, o presente trabalho objetiva analisar como nas Minas Gerais do século XVIII havia um consenso, que transitava pelos mais variados agentes sociais, de que boa parte das enfermidades era provocada por forças sobrenaturais, não raro associadas à ação de feiticeiras(os). Tal crença crivava tanto o reconhecimento e a explicação para as doenças como suas práticas terapêuticas e transitava de modo difuso por todos os agentes sociais que viveram nas Minas setecentistas - dos escravos aos senhores, dos cirurgiões e médicos aos curadores sem licença, normalmente perseguidos por seus feitos.

Para mergulharmos nesse universo das doenças de feitiço e percebermos como essa preocupação habitava de modo absolutamente assíduo a vida dos habitantes das Gerais ao longo do setecentos, usarei como principal corpus documental as denúncias contra os supostos agentes causadores dos malefícios reportadas aos órgãos persecutórios da Igreja: 
as devassas eclesiásticas, a cargo do bispado e o Santo Ofício da Inquisição. De modo acessório, igualmente lançarei mão de alguns tratados médicos coevos, para verificar como os agentes oficiais da cura, como médicos e cirurgiões, tratavam nessas obras a ocorrência dos feitiços e suas descrições.

\section{Como pensar as doenças? Breves considerações conceituais}

Nas últimas décadas, estudos que se debruçam sobre a temática das enfermidades e de suas formas de tratamento vem chamando atenção para a armadilha de um tipo de leitura que as naturaliza. Assim, como qualquer outro objeto de investigação histórica, as doenças devem ser igualmente historicizadas. Ou seja, devemos estar atentos para as diferentes formas de explicação e concepção dos males que acometiam os corpos de indivíduos que, vivendo em épocas diferentes da nossa, certamente possuíam outro tipo de arsenal mental para dar conta e remediar esse momento de fragilidade da existência humana.

Como nos ensina Canguilhem, existem possibilidades de pensarmos a construção e a aceitação de determinadas práticas e valores tomados como normais/naturais dentro de contextos históricos específicos com o fito de entendermos melhor as imbricações entre o biológico e o social, ao transformar em objeto de estudo a construção social de tais normas. ${ }^{2}$

Para o autor, um momento privilegiado para darmos conta da existência de um forte processo de normatização encontra-se na segunda metade do século XVIII e correr do século XIX, não coincidentemente associado à afirmação de um tipo de saber médico que cada vez mais estava preocupado com a descrição e quantificação das doenças, bem como com a utilização dessas estatísticas para a uniformização dos nomes das doenças. Para usar os conceitos de Canguilhem, buscava-se diferenciar o normal do patológico - sendo este último, visto, não raro, como desvio. Nesse processo, a norma é forjada de modo ambivalente: descritiva, ou seja, pensada como um conjunto de protocolos e formas de agir a serem devidamente seguidos, e prescritiva, uma vez que estava a ela imputada uma verdade existente a priori. ${ }^{3}$

1 As devassas eclesiásticas funcionavam ao nível do bispado, possuindo teoricamente uma periodicidade anual, em que o bispo - ou um subordinado indicado - iria percorrer arraiais e freguesias a propósito de conhecer e punir os pecados daquela comunidade mediante um conjunto de delitos pré-estabelecidos em quarenta quesitos, que eram perguntados a pessoas convocadas para contar o que sabiam na mesa da devassa. Para a organização das mesmas, bem como a análise dos delitos apresentados e ações repressoras, conferir FIGUEIREDO, Luciano. Barrocas famílias. Vida familiar em Minas Gerais no século XVIII. São Paulo: HUCITEC, 1997, p.41-8. Essa documentação organizada em códices manuscritos encontra-se sob a guarda do Arquivo Eclesiástico da Arquidiocese de Mariana (doravante, AEAM).

2 CANGUILHEM, Georges. O normal e o patológico. Rio de Janeiro: Forense Universitária, 1995, p.206; ELIAS Norbert. O processo civilizador. Rio de Janeiro: Zahar, 1990, p.88.

3 CANGUILHEM. O normal e o patológico, p.211 e 216. 
Outro autor fundamental para nos ajudar a pensar as práticas médicas e as complexas formas de conhecimento e percepção das doenças é Ludwik Fleck. Para este, a medicina deve ser encarada como uma ciência que se afasta da ocorrência de fenômenos regulares, como o funcionamento normal dos organismos: já que a própria constatação de uma doença por si só já acusa uma disfunção. Dessa forma, a delimitação de uma entidade nosológica só se torna possível através de um duplo olhar: a observação de variados casos individuais e um alto grau de abstração. ${ }^{4}$

Lançando mão de um estudo de caso, a gênese do conceito de sífilis, o autor forja o conceito de "fato médico". Segundo Fleck, o entendimento da sífilis como entidade nosológica singular passou por inúmeros caminhos ao longo do século XV. Identificada sobretudo como doença de Vênus (e portadora de diversos nomes como Morbus Gallico ou mal francês, scabies grossa), o que hoje chamamos sífilis fora identificado com inúmeras outras doenças venéreas e dermatológicas, ${ }^{5}$ além de ser envolta em uma série de explicações astrológicas, humorais, de caráter moral-religioso. Em contextos históricos diversos, as supracitadas formas de ver a doença, somadas a outras, informaram e moldaram as identificações e tratamentos do que hoje conhecemos como sífilis.

Rosemberg igualmente nos permite pensar a ocorrência de complexa interação entre o biológico e o social através do que o autor qualifica como enquadramento (framing) das doenças, ou seja, a percepção de como as doenças devem ser pensadas como entidades socialmente e historicamente forjadas, adquirindo especificidades que passam a ser concebidas como reais e particulares numa dada época e contexto social. Há, na escrita desse autor, uma preocupação patente nos intercâmbios entre o meio natural e as práticas sociais, fugindo de explicações que cairiam na dupla armadilha de considerar as doenças unicamente dados naturais ou como entidades meramente inventadas pelos homens. ${ }^{6}$

Nessa perspectiva, o autor sublinha que o enquadramento das doenças coloca em jogo diferentes atores e modifica de forma irresistível as vivências sociais, sobretudo no que versa sobre as relações médico-paciente, a construção de identidades individuais e de grupo, as fortes relações entre as doenças e valores culturais inerentes ao seu contexto de delimitação, entre outros aspectos.

Com isso, somos convidados a ampliar nosso olhar e tomar as doenças como interessante vetor a partir do qual podemos pensar aspectos da ordem religiosa, moral, ações de Estado e relações mais gerais de poder no cerne do momento histórico que escolhemos como objeto de estudo.

\footnotetext{
FLECK, Ludwik. La génesis y el desarrollo de un hecho científico. Madri: Alianza Editorial, 1986, p.18.

FLECK, Ludwik. La génesis y el desarrollo de un hecho científico, p.47 e 50.

Nas palavras do autor: "De certo modo, a doença não existe até concordarmos que ela exista, percebendo, nomeando e respondendo a ela". Tradução livre. ROSEMBERG, Charles. Explanning epidemics and others studies in the history of medicine. Cambridge: Cambridge University Press, 1992, p.305.
} 
Aliás, como prefere Rosemberg, as próprias concepções sobre os males humanos e as práticas de ação médicas - como toda e qualquer ação humana - não poderiam ser pensadas fora de seu contexto sócio-cultural, a exemplo das ferramentas intelectuais e técnicas à disposição de médicos para diagnosticar e tratar de uma dada doença num dado período. Daí o autor considerar tautológicos termos como história social da medicina ou construção social das doenças.

Assim, o enquadramento das doenças permite considerá-las socialmente cristalizadas e aceitas num dado contexto histórico. Dessa forma, a doença se converte - ela mesma - em ator a engendrar uma multifacetada rede de ações e negociações entre diferentes indivíduos. De acordo com o autor, uma vez devidamente enquadrada e aceita de modo consensual, uma dada doença, juntamente com outros atores sociais (médicos, pacientes, membros de grupos civis organizados, agentes do Estado, clérigos), passa à cena numa complexa trama. ${ }^{7}$

A partir desse referencial teórico, é possível perceber como, no curso do século XVIII, a crença mais ampla de que pessoas poderiam ser alvo de feitiços estava bastante enraizada também entre os habitantes dos arraiais auríferos. Assim, utilizo a ideia de consenso, tal como proposta por Rosemberg. O autor define consenso como o reconhecimento comungado e aceito por vários atores sociais que uma dada doença existe, possuindo ela um determinado nome, além de um conjunto de características que Ihe são próprias, e, por isso, passíveis de reconhecimento e intervenções, como práticas terapêuticas, imposição de quarentena, repressão contra agentes sociais responsabilizados como causadores ou transmissores dessa doença. ${ }^{8}$

Contudo, isso não quer dizer que o feitiço tenha sido concebido de modo unívoco e/ou imutável ao longo do período estudado. Como nos ensina Stuart Clark, analisando os tratados demonológicos e as crenças doutas acerca da feitiçaria na Europa Moderna, havia considerável variação e, sobretudo, articulação com outras esferas da produção de conhecimento, como o pensamento científico, as concepções religiosas e políticas em tempos e lugares diversos, a influenciar diretamente as descrições das ações das feiticeiras, seus poderes e males que provocavam. Assim, esse autor coloca em revelo, mesmo, a existência de demonólogos mais céticos ou aqueles que agiam com certa cautela ao definir as práticas perpetradas pelas feiticeiras. ${ }^{9}$

7 Para uma discussão que igualmente contemple a variável aceitação de explicações para a ocorrência de determinadas doenças, bem como as articulações de redes e diferentes atores (sejam estes humanos ou nãohumanos), conferir, LATOUR, Bruno. Give me a laboratory and I will raise the world. In: MAULKAY, M. (ed.) Science observed: perspectives on the social study of science. Londres: Sage, 1983.

8 ROSENBERG, Charles. Explaining epidemics and others studies in the history of medicine, p.315-316.

9 CLARK, Stuart. Pensando com demônios. A ideia da bruxaria no princípio da Europa Moderna. São Paulo: EDUSP, 2006, p.261-283. 
Mais especificamente para o contexto luso, Pedro Paiva afirma o significativo e duradouro peso do tomismo na formação dos doutos, responsável por criar uma atmosfera de menor credulidade quanto aos poderes do diabo e às ações extraordinárias que ele poderia promover junto a seus sequazes, como metamorfoses e vôos para encontros noturnos. Modo de pensar que consequentemente gerava uma atitude de maior cuidado, e mesmo ceticismo, por parte de alguns juízes, inquisidores e padres responsáveis por devassas ao se verem diante de determinadas acusações. Não obstante, não se pode dizer que havia em terras lusas desconhecimento sobre a ação das bruxas e sua íntima relação com o "Príncipe das Trevas", com direito à circulação e ao contato atualizado com as obras que discutiam o tema. Ainda que de modo difuso, essa matéria fazia parte das preocupações das elites letradas em Portugal. Assim, as ações das bruxas marcavam presença nas páginas de obras como o corpus legislativo das três instâncias que reprimiam a feitiçaria, a exemplo das Constituições Diocesanas, Ordenações Régias e Regimentos Inquisitoriais; nos textos eclesiásticos, como manuais de confissão, exorcismo e catecismos; e nos tratados de medicina, onde era bastante recorrente, como procuro mostrar adiante, a descrição dos feitiços e seus sintomas. ${ }^{10}$ Sendo alguns desses tratados médicos, como dito, utilizados pontualmente para a confecção deste artigo.

Outra faceta que merece menção, embora seja discutida mais brevemente, em função dos interesses mais específicos e limites deste texto, são as significativas mudanças em torno da definição e descrição das doenças, sobretudo na segunda metade do século XVIII, por conta das novas premissas e métodos de ação sobre o corpo doente oriundos da medicina das Luzes.

A historiografia mais diretamente ligada à medicina igualmente tem salientado a existência, desde a Antiguidade, de tradições médicas que buscam tratar do adoecimento e da cura como sendo exclusivamente vinculados a fatores naturais. O renascimento do hipocratismo no século XVII e a medicina das Luzes seguem essa vertente e se contrapõem, muitas vezes, às práticas e concepções médicas que incluíam a crença na ação de feitiços. As próprias discussões sobre magia, ação à distância, simpatias e demais fenômenos ligados a curas e doenças têm sido objeto de estudos recentes, além de contar com estudos já clássicos. ${ }^{11}$

Nessa perspectiva, os conceitos apresentados acima serão aplicados à análise, o que permite considerar, grosso modo, como crença comum e espalhada por vários extratos sociais a ocorrência das doenças de feiti-

10 PAIVA, José Pedro. Bruxaria e superstição num país sem "caça às bruxas". Lisboa: Notícias, 2002, p.336-340 e p.19-22.

11 Tal discussão pode ser acompanhada, entre outros autores, em: GARIN, Eugenio. (org.) O homem renascentista. Lisboa: Presença, 1991; ZILLER, Carlos. O unguento de armas na construção da ação à distância. In: V Encontro do Ensino de Engenharia. Rio de Janeiro, 1999; THORNDIKE, Lynn. Place of magic in the intellectual history of Europa. New York: The Columbia University Press, 1905; THOMAS, Keith. Religião e o declínio da magia. São Paulo: Companhia das Letras, 1991. 
ço. A partir de agora, passemos ao conhecimento dos temidos feitiços e feiticeira(o)s que habitavam as Minas setecentistas.

\section{Feitiço: mal onipresente}

No ano de 1743 um negro chamado Bardara teria seus feitos contados na mesa de uma das devassas eclesiásticas engendradas nas Gerais do século do ouro. Qualificado como feiticeiro, pesava sobre Bardara a acusação de produzir malefícios contra um parceiro de mesma cor, que não tem seu nome explicitado na denúncia, em funções de "razões" entre ambos. Achando-se seu desafeto a comer uma espiga de milho, Bardara resolveu que "não havia de chegar de acabar de comer o espigão, pelo que dera uma volta por detrás dele o dito parceiro e este caio no chão doente de cuja doença sempre depois veio morrer". ${ }^{12}$

Movido igualmente por ódios pessoais também agiria em 1751 um escravo que nos é apresentado apenas como "um negro velho de nação mina", sendo responsável pela confecção de feitiços contra Antônio. Ele, de acordo com o denunciante, "padecia moléstia a que não pode dar remédio". O motivo concreto da vingança encetada pelo escravo feiticeiro não chega até nós, restringindo seu denunciante a mencionar que o escravo "tinha dado malefícios por umas razões anteriores que se tinha tido e com isso faleceu em breves dias". ${ }^{13}$

Cerca de dez anos depois das ações de Bardara outro negro, um escravo de nome João, seria alvo de várias denúncias por ser responsável pela produção de feitiços que levaram a óbito vários escravos de diferentes senhores. Um de seus denunciantes foi Antônio José de Almeida - "que vive de sua arte cirúrgica" - que, ao ser chamado para curar um escravo de Maria "que na enfermidade conheceu ser extranatural", acabou com esse argumento a embasar a denúncia contra o suposto agente da doença que fora incapaz de curar por extrapolar suas habilidades médicas. ${ }^{14}$

O lisboeta Lucas de Golveia, no ano de 1757, teria sua vida e fazenda supostamente aviltadas por uma negra chamada Victória. Infamada feiticeira que era, objetivava deixar o senhor miserável, "apenas com um pão na mão", e por isso fora acusada de produzir malefícios contra a escravaria de Gouveia. Uma das denúncias contra seus feitos desnuda de modo bastante interessante a manipulação das doenças de feitiço e as diferentes formas de domínio do mundo sobrenatural, fosse para provocar doenças, fosse para engendrar tratamentos, deixando entrever, uma vez mais, disputas profissionais no campo da cura:

12 AEAM. Devassas Eclesiásticas, 1743, f.1v.

13 AEAM. Devassas Eclesiásticas, 1750-1753, f.40.

14 AEAM. Devassas Eclesiásticas, 1750-1759, f.97v. 
Estavam a morrer algumas pessoas na casa apresadamente e também alguns escravos desconfiando ele testemunha que seriam feitiços, por acaso achou um negro que the disse sabia curar o qual se chama José Cabus e vindo este a casa dele testemunha the curou um negro dizendo que a sua moléstia eram feitiços que a dita Victoria Ihe tinha feito isso depois de terem morrido seis escravos que o tal negro Jozé Cabus disse morrerão dos mesmos feitiços. ${ }^{15}$

Enfim, na freguesia dos Prados em Mariana - lugar referido pelo denunciante sugestivamente como "aldeia das feiticeiras" - morava uma mulata forra de nome Florência, que fora denunciada ao Santo Ofício por fazer diversos feitiços. Uma de suas vítimas teria sido o alferes Domingos Róis Dantas, seu senhor, pressionado a alforriar Florência que além de prejudicar sua saúde ainda impedia-lhe o casamento. Tomando conhecimento dos feitos de sua mulata o alferes tentaria adverti-la em vão:

Vem cá porca feiticeira para que tu enterraste esta porcada aqui em minha porta? Disse ela: Vossa Mercê não há de casar e eu ficar cativa toda a minha vida, ainda que eu saiba ir para o inferno, e senão, com os mesmos remédios Ihe hei de tirar a vida. ${ }^{16}$

Esses casos já deixam pouca margem de dúvidas para percebermos como a crença nos achaques provocados pela confecção de feitiços encontrava-se imbricada na explicação e definição dos vários males que afetavam a saúde dos habitantes nas Minas ao longo do setecentos.

Nesse esteio, deve ser sublinhada a própria forma de construção das denúncias pesquisadas: as expressões doença, moléstia, enfermidade são usadas simultaneamente e, por vezes, quase de modo intercambiável com outras como feitiço e malefícios, como é possível ler na fala dos acusadores: "a sua moléstia eram feitiços"; "na enfermidade conheceu ser extranatural". Além disso, é igualmente recorrente encontrarmos construções como "morreu sem ferimento algum"; "padecia de doença a que não se pode dar remédio"; "morreu apressadamente"; "tinha dado malefícios", que reforçam ainda mais esse entrelaçamento entre o natural e o sobrenatural/mágico, como alguns dos denunciantes faziam questão de narrar aos padres responsáveis pelas devassas, frisando, por vezes, a não existência de traços externos no corpo doente e/ou a ocorrência súbita da morte como indício da presença de feitiços.

Em outros momentos, me deparei com expressões retiradas das denúncias como "padecia de doença a que não se pode dar remédio"; "doenças que podiam nascer de malefícios"; "doente de feitiço"; "dor de feitiço". Somando-se a essas crenças a própria iniciativa de alguns cirurgiões,

15 AEAM. Devassas Eclesiásticas, 1756-1757, f.184-184v.

16 Portugal. ANTT. Inquisição de Lisboa. Cadernos do Promotor, n.130. Devo a transcrição desse caso e de outros que serão analisados no curso deste trabalho à generosidade de Luiz Mott, a quem fica aqui registrada minha gratidão. 
sobretudo nas primeiras décadas do século XVIII, de definir e descrever, como tratarei mais adiante, vários "sintomas de feitiços", mostrando forte consonância com o tipo de escrita que utilizavam a propósito enquadrar as outras enfermidades que habitavam suas obras. Nessa perspectiva, parece ser possível pensar num esforço, tanto de autoridades eclesiásticas como da medicina oficial, em categorizar os diversos tipos de achaques provocados pela ação desses supostos feiticeiros. Assim, as fontes compulsadas nos dão pistas da forja de certa sintomatologia em torno das enfermidades provocadas pelos feitiços, sublinhando e arrolando males como dores, mortes repentinas ("sem ferimentos", como aparece nas acusações), apatia, inchaços, impotência sexual (ligamento), entre outros, que minavam o corpo, a mente e o comportamento das vítimas.

Outro dado que não pode ser negligenciado é que tanto nas diversas culturas da Europa do Antigo Regime como para os múltiplos povos oriundos do continente africano existia, de modo pacífico, a crença de que pessoas poderiam manipular forças sobrenaturais para a produção de feitiços. ${ }^{17} \mathrm{Tam}$ bém nas Gerais tais explicações, que a despeito das suas especificidades possuíam fortes interseções, mesclavam-se e alimentavam ainda mais o medo do feitiço que abarcava indivíduos das mais diversas procedências, estratos sociais e cores de pele.

Com tal observação, não objetivo aqui defender a ideia de que não havia especificidades e diferenças em torno das práticas de feitiçaria, ${ }^{18}$ mas, por outro lado, numa parcela bastante expressiva dos casos por mim pesquisados - ou da forma com que esses nos chegam, filtrados pelas crenças e escrita dos clérigos - as suspeitas da existência dos feitiços por si já eram suficientes para desencadear as denúncias na mesa das devassas, não raro sem que as supostas vítimas de tais malefícios mostrassem uma preocupação posta em rastrear sua origem.

Mais uma vez, é necessário historicizar o conceito de doença, no curso do período estudado, para melhor compreender a ação dos feitiços. Sergio Buarque de Holanda, em abordagem pioneira, já havia chamado atenção para o fato de que "a medicina e a magia primitivas não conheceu nenhuma distinção nítida entre malefício e moléstia". Assim, na percepção dos

17 Entre outros autores, conferir: PAIVA, José Pedro. Bruxaria e superstição num país sem "caça às bruxas"; NOGUEIRA, Carlos Roberto Figueiredo. Bruxaria e História: as práticas mágicas no ocidente cristão. Baurú: EDUSC, 2004; THOMPSON, Robert Farris. Flash of the spirit. New York: Vintage Books, 1984; MANDROU, Robert. Magistrados e feiticeiros na França do século XVII. São Paulo: Perspectiva, 1979; GINZBURG, Carlo. História noturna: decifrando o sabá. São Paulo: Companhia das Letras, 1990; GINZBURG, Carlo. Os andarilhos do bem: feitiçarias e cultos agrários nos séculos XVI e XVII. São Paulo: Companhia das Letras, 1990; EVANS-PRITCHARD, Edward E. (1976). Bruxaria, oráculos e magia entre os Azande. Rio de Janeiro: Zahar, 2005.

18 Para tal discussão, por exemplo, conferir os argumentos de J. Thornton. O autor especifica algumas concepções de feitiçaria que seriam próprias aos africanos centro-ocidentais. Embora igualmente sublinhe outros aspectos comuns aos povos africanos e europeus. Acerca dessas diferenças, nas palavras do autor: "As diferenças entre as idéias africanas e européias sobre o mal - entre o diabo como autor de todo ele, e o uso que pessoas perversas faziam de forças espirituais amorais para fins maldosos - era também a diferença entre as tradições de feitiçaria em ambas as culturas". THORNTON, John. Religião e vida cerimonial no Congo e áreas Umbundo, entre 1500 a 1700. In: HEYWOOD, Linda M. Diáspora negra no Brasil. São Paulo: Contexto, 2009, p.92ss. 
paulistas acerca dos achaques que os afligiam havia margem significativa para pensar, numa chave mental muito próxima e, não raro, imbricada, "frechadas", ataques de animais ferozes como onças, sezões e os temidos malefícios. ${ }^{19}$

Nessa perspectiva e consoante com a fala do cirurgião bragantino Antônio José de Almeida de que existiam enfermidades que ele reconhecia como extranaturais, ${ }^{20}$ podemos notar que a percepção de que diversos achaques seriam provocados por feitiços era uma realidade comungada não apenas entre as camadas desclassificadas do Antigo Regime. Aliás, como já mencionado, no discurso da medicina oficial havia significativo espaço para sua teorização, detalhamento e sugestão de tratamentos.

Cirurgião licenciado, após aprendizado prático e estudos no Hospital Real de Todos os Santos de Lisboa, e atuante em diversos povoados e cidades das Minas por aproximados dez anos, Luis Gomes Ferreira, em seu Erário Mineral, dedica uma seção inteira sobre os métodos "para curar enfeitiçados e ligados por arte mágica ou malefícios". Nela o autor faz eco aos princípios mais clássicos do pensamento demonológico da época, valendo-se igualmente dos textos do famoso médico português Curvo Semedo para dar maior legitimidade à sua escrita. Ferreira, sem deixar dúvidas, corrobora a existência de feitiços e feiticeiras(os):

E ao Dr. João Curvo diz o mesmo (...) por entender que alguma mulher enganada pelo demônio ou por algumas feiticeiras, que são seus ministros, Ihe aconselhara que, para conciliar a amizade do tal homem, Ihe desse o sangue mensal, e como o dito sangue não tem tal virtude, ante seja tão perverso e venenoso que não só causa os ditos efeitos de loucura. ${ }^{21}$

Em seu Medicina Lusitana, é socorro déphico a os clamores da natureza humana, para total profligação de seus males, que no ano de 1731 já contava com uma segunda edição, Francisco da Fonseca Henriques, médico do rei dom João V, corrobora com a crença na existência e no poder de maleficar das bruxas. No capítulo 108 de seu tratado, "Da atrophia ou extenuaçam dos meninos", o autor faz eco ao medo dos infanticídios tão comumente atribuídos aos feitiços:

Que se secam os meninos pelos chuparem as bruxas, que são huas mulheres que tem pacto com o Demonio, e se convertem em humas aves noturnas a

19 HOLANDA, Sérgio Buarque de. Caminhos e fronteiras. Rio de Janeiro: José Olympio, 1957, p.105-147.
20 AEAM. Devassas Eclesiásticas, 1750-1759, f.97v.

21 FERREIRA, Luís Gomes. Erário mineral [1735]. Belo Horizonte: Fundação João Pinheiro, 2001, p.422. 
que chamão striges, ou porque adistringem e apertão de noite a garganta dos meninos. ${ }^{22}$

Brás Luís de Abreu, que além de atuar como médico formado ainda era familiar do Santo Ofício, possuía, ao que parece, duplo motivo para acreditar e rastrear a ação de feiticeiras(os). Não é por mero acaso que sua obra, Portugal Médico, publicada em 1726, é uma das mais consistentes e detidas na descrição das práticas desses agentes e acusa amplo conhecimento e diálogo do autor com os tratados demonológicos. Ao descortinar as supostas artimanhas do diabo, Abreu categoriza como médicos-feiticeiros tanto os produtores de malefícios - que são alvo de maior atenção em sua pena - como os curadores ilegais, chamados de mezinheiros e benzedores ao longo do tratado. Colocava, com isso, indistinta e propositalmente os indivíduos que provocavam o mal via doenças de feitiço e os curadores sem licença no mesmo plano, identificados como sequazes do Inimigo de Cristo.

Após observar com erudição as nuances do pacto demoníaco, em detaIhes normalmente não observados por seus pares, ${ }^{23}$ o médico e funcionário da Inquisição passa a salientar a ação das feiticeiras, não se esquecendo de marcar suas graves diferenças de atuação e formação acadêmica, como artifício de retórica:

Estas almas perdidas logo tratão de ser medicas da Universidade do Inferno; cujo officio é somente matar e destruir por todos os caminhos o gênero humano. $E$ para sahirem com esta empreza em que o inimigo comum as industria, buscão e procurão com intestino ódio meninos lactantes; e nestes fazem o mais lastimozo estrago (...) como quer Martim Del Rio. ${ }^{24}$

Outro médico luso, Bernardo Pereira, igualmente reconhece a existência de forças sobrenaturais usadas como veículo da alteração da saúde das pessoas, sugerindo como tratamento sacramentos e exorcismos, associando-os, ainda, a purgas, sangrias e vomitórios, por estar convencido de que determinados achaques "dependem de cura não só na escola de Galeno, mas na religião católica". ${ }^{25}$ Dessa forma, como as doenças eram muitas vezes vistas como um misto indissociável de causas naturais e sobrenaturais, havia significativo espaço para o uso dos remédios espirituais,

22 Há grande relação, em Portugal, entre feitiçaria e infanticídio em função do mito da strix, ave noturna que sugava o sangue das crianças, como podemos encontrar no próprio dicionário de Raphael Bluteau: "Em português chamamos bruxas umas mulheres, que se entende, que matam as crianças, chupando-lhe o sangue. Bruxa em latim pode se chamar strix. Fem. que é o nome de uma ave infausta e noturna (...) e é opinião de graves autores, que esta mesma ave quando se lhe oferece ocasião também chupa aos meninos o sangue". BLUTEAU, Raphael. Vocabulário portuguez e latino. Coimbra: Colégio das Artes da Companhia de Jesus, 1728, p.710. Para tal discussão, conferir, BETHENCOURT, Francisco. O imaginário da magia: feiticeiros, saludadores e nicromantes no século XVI. Lisboa: Universidade Aberta, 1987, p.88ss.

23 PAIVA, José Pedro. Bruxaria e superstição num país sem "caça às bruxas", p.41.

24 ABREU, Brás Luís de. Portugal médico. Coimbra: Oficina de Joam Antônio, 1726.

25 PEREIRA, Bernardo. Anacephaleosis médico, theológica, mágica, jurídica, moral e política. Coimbra: Oficina de Francisco Oliveyra, 1734, p.181. 
o que gerava igualmente um forte imbricamento entre o discurso médico e o religioso no curso do período estudado. ${ }^{26}$

Tal realidade pode ser vista, mais uma vez, num manual de exorcismo escrito pelo padre italiano Candido Brognolo, que ganhou tradução e significativo uso em terras lusas. ${ }^{27}$ Nessa obra, em vários trechos o autor associa e descreve diversos sintomas físicos como indícios da presença diabólica na confecção da doença, além de propor um intenso diálogo entre as práticas médicas e a ação dos padres exorcistas, possuindo inclusive uma benção específica a ser aplicada nos remédios receitados aos enfermos. Mesmo sendo clérigo exorcista e não médico, o autor dedica em sua obra considerável espaço para a descrição dos males do corpo e os associa à ação das feiticeiras; nessa altura do tratado podemos perceber, inclusive, seu conhecimento e confecção de explicações ancoradas na teoria hipocrático-galênica dos humores: ${ }^{28}$

Feito pois pela perversa creatura pacto com o demônio, e também feitos taes, ou quaes finaes de feitiço, com o demônio os engana, insinuando-lhes que os occultem, para que o feitiço com assistência do mesmo demônio prevaleça (...) principia logo a obrar conforme a vontade do maléfico ou feiticeiro, e observando os humores da creatura, a atormenta de muitos modos. ${ }^{29}$

No teor dos tratados médicos e mesmo em obras tão variadas como manuais de exorcismo e dicionários, podemos observar a indelével intimidade que parte dos letrados lusos possuía com a literatura demonológica, que corrobora os argumentos de Pedro Paiva. Segundo o autor, como já mencionado acima, a despeito da não ocorrência de uma perseguição às bruxas que chegasse perto de outras partes da Europa, como a Suíça e a França, e, consequentemente, da não existência de uma sólida e específica produção intelectual que sustentasse tais práticas, como os manuais de caça às bruxas, em terras lusas não faltou conhecimento e debate em torno dessa matéria. Nessa perspectiva, as armadilhas do diabo e seus sequazes - principalmente os produtores de malefícios - faziam-se presentes. ${ }^{30}$ Uma leitura dos argumentos e das citações dos cirurgiões e médicos que escreveram sobre a doença e a cura tanto do Reino quanto de suas colônias nos permite o encontro com as obras clássicas acerca do tema, como

26 SOUZA, Laura de Mello. O diabo e a Terra de Santa Cruz: feitiçaria e religiosidade popular no Brasil colonial. São Paulo: Companhia das Letras, 1995; RIBEIRO, Márcia. Exorcistas e demônios: demonologia e exorcismos no mundo luso-brasileiro. Rio de Janeiro: Campus, 2003; RIBEIRO, Márcia. A ciência dos trópicos: a arte médica no Brasil do século XVIII. São Paulo: HUCITEC, 1997; GROSSI, Ramon Fernandes. A arte da cura: uma contribuição para o estudo da medicina na Capitania das Minas (1750-1808). Cronos, Pedro Leopoldo, n.8, p.140-164, abr. 2005.

27 RIBEIRO, Márcia. Exorcistas e demônios: demonologia e exorcismos no mundo luso-brasileiro, p.64.

28 JORDANOVA, Ludmilla e PORTER, Roy. Images of the earth. Essays in the history of the environmental sciences. Oxford: Alden Press, 1997, p.128ss.; NUTONN, Vivian. Humoralism. In: BYNUN, W.F. and PORTER, Roy. Companion encyclopedia of the history of medicine. Londres e Nova lorque: Routledge, 1997, p.281-291.

29 BROGNOLO, Candido. Brognolo recopilado e substanciado com aditamento de vários autores. Tradução Frei José de Jesus Maria. Coimbra: Oficina de Francisco Borges de Souza, 1757, p.49. (Grifo nosso).

30 PAIVA, José Pedro. Bruxaria e superstição num país sem "caça às bruxas", p.20-21. 
podemos vislumbrar nas páginas de Brás Luiz de Abreu, que se utilizava de autoridades como DelRio e o jurista espanhol Torreblanca para dar corpo às suas relações entre doenças e feitiços.

Aliás, nas Minas do século XVIII algumas das denúncias encontradas nas devassas eclesiásticas ou reportadas aos agentes do Santo Ofício, além de reforçarem a existência das doenças de feitiço, como venho insistindo, também ventilam fragmentos desse discurso demonológico erudito. Nosso já conhecido feiticeiro Bardara, além de vitimar seu parceiro com malefícios supostamente colocados numa espiga de milho ainda foi acusado de ter feito pacto com o diabo. Em sua fala, o bragantino Luiz Pereira de Sá afirma que Bardara "era feiticeiro e tinha familiar e pacto com o demônio". ${ }^{31}$ O recurso aos familiares - diabretes que ajudam os feiticeiros depois de firmado o pacto demoníaco - era presença constante nos tratados demonológicos europeus ${ }^{32}$ Assim, o denunciante português, ou o padre notário da devassa por ele, transplantaria os medos provenientes do Velho Mundo para suas colônias. Entretanto, consoante com os interesses mais específicos deste artigo, deixarei aqui de lado essa íntima relação que por vezes é possível detectar entre as denúncias que acusavam os feiticeiros que habitaram as Minas setecentistas e os conceitos da demonologia erudita também presentes em terras lusas.

Outro vetor que não deixa de chamar atenção é a permanência que por vezes as crenças no poder de feitiços e feiticeira(o)s aparecem nas denúncias reportadas aos padres responsáveis pelas devassas eclesiásticas.

Como é sabido, sobretudo na segunda metade do século XVIII, há significativas mudanças no que versa sobre a definição e descrição propriamente médicas das doenças, fortemente embaladas pelas influências da multifacetada llustração. ${ }^{33}$ De forma esquemática, é possível elencar algumas dessas mudanças cruciais no âmbito dos saberes médicos. Primeiramente, há uma valorização cada vez maior da experimentação e da observação. Assim, o corpo doente seria esquadrinhado amiúde, visando a produção de estatísticas e mapas de doenças feitos mediante exames cada vez mais padronizados de doentes em hospitais e a dissecação daqueles que não resistiram às enfermidades. Para tanto, era preciso observar os corpos enfermos em quantidade e frequência. O desenvolvimento da observação clínica fazia-se colado ao espaço hospitalar, cada vez mais dominado e regrado pelos médicos. Em terras lusas, como afirmam Jean Abreu e Márcia Ribeiro, é possível perceber o aumento da entrada e do diálogo com os autores estrangeirados e a vanguarda da produção ilustrada, a exemplo

31 AEAM. Devassas Eclesiásticas, 1743, f.5v.

32 KRAMER \& SPRENGER. Malleus maleficarum [1484]. Rio de Janeiro: Rosa dos Tempos, 1990, p.77.

33 Penso aqui a ampla e complexa llustração em convergência com as considerações de Lorelai B. Kury: "Longe de designar somente um conjunto de idéias, as Luzes englobam, é certo, conceitos, mas também modos de agir". KURY, Lorelai. Iluminismo e império no Brasil: o patriota (1813-1814). Rio de Janeiro: Fundação Oswaldo Cruz, 2007, p.2. 
de nomes como Tissot, Ribeiro Sanches, Vandelli e Vigier, o que nos força, inclusive, a repensar visões tradicionais de atraso intelectual de parte dos doutos portugueses em relação ao conhecimento do que era produzido e do que circulava na Europa das Luzes. Sem contar com uma preocupação constante com o exercício e ensino de anatomia, através das dissecações, da maior aproximação entre a medicina e a cirurgia e a patente influência de vertentes mecanicistas no saber médico luso. ${ }^{34}$

Entretanto, tais mudanças e afirmações dessas novas formas da medicina no definir e descrever as enfermidades e suas causas não se processou de modo linear. ${ }^{35}$ Ramon Grossi destaca, para o contexto das Minas na segunda metade do século XVIII, um panorama de mudanças e permanências (palavras do autor) que pode ser visto tanto pela introdução da inoculação antivariólica na Capitania, por volta de 1799, como pela manutenção de explicações para os achaques fortemente marcadas pelas forças sobrenaturais. ${ }^{36}$

Várias denúncias tiradas das devassas eclesiásticas nos servem para corroborar os argumentos desse autor e, como já indicado acima, dar mostras da longevidade das crenças nos supostos produtores de malefícios. Nesse sentido, a parda Timótia Nogueira foi acusada de ter o poder de fazer "vir a presença do diabo todas as vezes que queria". Uma vez mais em ação, a feiticeira Timótia "por ódios" contra uma negra chamada Rita ofereceu-lhe um caldo de galinha com feitiços. Esta, desconfiada da inusitada gentileza, "lançou" o quitute para um cão que acabou levando a pior. ${ }^{37}$ Uma negra forra de nome Ana, moradora no Morro Vermelho, igualmente era acusada de "com feitiços" ter matado alguns negros. ${ }^{38}$ Note que os supostos malefícios e a assídua comunicação com o diabo que aparecem nas denúncias contra as feiticeiras Timótia e Ana datam da mesma época em que o regimento ilustrado da Inquisição pombalina, no ano de 1774, assevera teológica, jurídica e geometricamente, em sintonia com novas formas de pensar no presente século iluminado, que as ações das feiticeiras seriam muito mais "fenômenos das paixões histéricas e das interpeladas imaginações do sexo feminino", não condizendo, assim, com a "sisudeza" e

34 Para uma discussão mais adensada dessas mudanças no cenário médico, sobretudo na segunda metade do século XVIII, que, em muito não tocam os interesses mais específicos deste artigo, conferir entre outros autores: JORDANOVA, Ludmilla and PORTER, ROY. Images of the Earth, p.137ss.; ABREU, Jean. Ilustração, experimentalismo e mecanicismo: aspectos das transformações do saber médico em Portugal no século XVIII. Topoi. Rio de Janeiro, v.8, n.15, p.80-104, jul.-dez. 2007; FOUCAULT, Michel. O Nascimento da Clínica. Rio de Janeiro: Forense Universitária, 2004, p.119-123; WEINER, Doara B. e SAUTER, Michael J. The city of Paris and the rise of clinical medicine. Osiris, Chicago, n.18, 2003; RIBEIRO, Márcia. Exorcistas e demônios. Especialmente a parte III; MARQUES, Vera B. Magia e Ciência no Brasil Setecentista. In: Chalhoub et al. Artes e Ofícios de Curar no Brasil. São Paulo: Editora Unicamp, 2003, p.163-195.

35 MARQUES, Vera B. Magia e Ciência no Brasil Setecentista, p.177ss.; ABREU, Jean. Ilustração, experimentalismo e mecanicismo, p.80; PORTER, Roy. The greatest benefit to manking: a medical history of humanity. Nova lorque: WW. Norton \& Company, 1999, p.266.

36 GROSSI, Ramon Fernandes. A arte da cura, p.155-161.

37 AEAM. Devassas Eclesiásticas, 1767-1777, f. 67-69.

38 AEAM. Devassas Eclesiásticas 1767-1777, f.77v. 
o "decoro" do Santo Ofício. ${ }^{39}$ Numa outra devassa eclesiástica, endereçada à Aplicação de São Caetano de Paraopeba, em 1800, um padre chamado José de Carvalho fora acusado de ter solicitado os préstimos de uma negra infamada feiticeira para realizar adivinhações. ${ }^{40}$ Assim, as bruxas e seus poderes, ao que parece, continuaram a marcar presença nos arraiais auríferos, mesmo no último ano do Século das Luzes.

\section{Óbitos, "tolhimentos" e "dores": os sintomas e efeitos dos feitiços}

A possibilidade de leitura aqui proposta, de pensarmos o feitiço como um dos agentes propiciadores de enfermidades, não se limita apenas a afirmação de sua existência e ao longo tempo em que nele se acreditava. Nessa perspectiva, deparamo-nos com uma série de descrições dos males do corpo e da alma que as ações das(os) feiticeiras(os) produziriam. Tais sintomas de feitiços podem ser encontrados tanto nas denúncias extraídas dos aparelhos persecutórios da Igreja como das páginas escritas por cirurgiões e médicos. ${ }^{41}$

Assim, o cirurgião Gomes Ferreira sublinha em seu tratado que encontrara vários de seus pacientes faltos de apetite, "secos como esqueletos", impedidos de realizarem o ato sexual (estar "ligado", como aparece na documentação coeva), "inchados como pipas","tontos e mentecaptos", entre outros achaques por "se acharam enfetiçados ou endemoniados". ${ }^{4}$

Tal qual fizera o cirurgião Gomes Ferreira dez anos depois, no tratado médico de Abreu também podemos vislumbrar a preocupação em descrever os sintomas sofridos pelos "doentes de feitiço". Tais variavam das perturbações mentais, como ficarem "furiozos e loucos" até a morte súbita. No que tange à capacidade dos malefícios "cauzarem achaques e mortes", mesmo considerando a possibilidade da manipulação de substâncias venenosas, o autor não deixa de sublinhar a dimensão sobrenatural da ação das bruxas:

Os quais uguentos, e pos humas vezes são aptos para cauzarem achaques e mortes por sua natureza, e qualidades, porque podem ser feitos de ingredientes venenozos, que o Demonio Ihes mostra e ensina; como adverte Torreblanca. Outras vezes cauzão os mesmos males, não por virtude natural, que para isso

39 REGIMENTO do Santo Ofício da Inquisição do Reino de Portugal de 1774. Revista do Instituto Histórico Geográfico Brasileiro, Rio de Janeiro, n.392, p.950-951, jul./set. 1996.

40 AEAM. Devassas Eclesiásticas, 1800, f.28v.

41 Uso a expressão "sintomas de feitiços" por dois motivos. Primeiramente porque ela, por vezes, aparece na própria documentação coeva. Gomes Ferreira, por exemplo, além dos males que relata, faz menção à ocorrência de "outros mil sintomas tão horrendos" para enfatizar a ação das bruxas. FERREIRA, Luís Gomes. Erário mineral [1735], p.422. E depois porque, mesmo quando o termo não aparece literalmente nos tratados, a forma de descrever o feitiço como causador de doenças e seus desdobramentos nos corpos enfeitiçados se assemelha de modo patente com a que esses autores descrevem as outras doenças referidas em suas obras e que não tinham como causa a manipulação de forças sobrenaturais para fins de produção de malefícios.

42 FERREIRA, Luís Gomes. Erário mineral [1735], p.423. 
tenhão; mas porque o Demonio por força do pacto se obriga a que elles rompão os mesmos effeitos. ${ }^{43}$

No manual de exorcismo de Candido Brognolo foi onde encontrei maior descrição dos sintomas provocados pelas vexações do demônio, fossem diretas, fossem por meio de seus principais sequazes, as bruxas e os bruxos. O padre exorcista, ao elencar o vasto repertório de achaques provocados pelo "Inimigo da Cristandade", ainda nos brinda, uma vez mais, com seus conhecimentos de medicina e sofistica seu diálogo entre as teorias humorais e as doenças de feitiço:

Mandando-Ihe a fantezia, e os sentidos corporaes ou tornando o corpo aereo, ou mostrando aos vexados serpentes, touros, feras medonhas, ou figuras horrendas. De dentro atormentando, e comprimindo as entranhas, e partes inteiras do corpo causando dores, chagas, grandes agitações e moléstias (...).

Quando o demonio faz semelhante entrada, costuma em que parte daquelle composto fysico póde haver mais facilmente alguma enfermidade porque então mais Ihe aballa os taes humores, inquieta os espiritos, e perturba as potencias, havendo muytas imaginaçoes e às vezes fazem os homens mudos, surdos, coxos, cegos, febricitantes, gerão gravíssimas enfermidades, e outros tormentos grandes. ${ }^{44}$

Brognolo ainda explica em maiores detalhes que o humor sobre o qual o demônio mais atuava era o melancólico, justificando a preferência em função de duas características marcantes desse humor: "porque com maior dificuldade se tira" e "porque o humor melancolico é o mais apto a gerar diversas enfermidades, e incuráveis". ${ }^{55}$ O padre exorcista lança mão da autoridade de Galeno e Avicena para embasar seus argumentos acerca da composição dos humores nos organismos. Aqui, novamente, deparamo-nos com fronteiras plásticas entre as crenças religiosas e o discurso médico no curso do período estudado: médicos e cirurgiões teorizavam e tratavam de feitiços e enfeitiçados; padres exorcistas davam cabo das variações dos humores nos corpos humanos. O natural e o sobrenatural no mais das vezes eram indissociáveis.

Aliás, é possível notar na pena de Gomes Ferreira, Brognolo e Abreu alguns pontos comuns ao elencarem os sintomas sofridos pelos doentes de feitiço: ênfase na debilidade física que poderia até provocar o óbito das vítimas, desequilíbrio e perturbações mentais. Não é difícil pensar na circulação, influências mútuas e possibilidades de leituras e apropriações entre os cirurgiões e médicos que escreviam suas obras, a exemplo da referência direta de Gomes Ferreira às obras de Curvo Semedo para ba-

43 ABREU, Brás Luís de. Portugal médico, p.630.

44 BROGNOLO, Candido. Brognolo recopilado e substanciado com aditamento de vários autores, p.14-15.

45 BROGNOLO, Candido. Brognolo recopilado e substanciado com aditamento de vários autores, p.15. 
lizar suas considerações sobre a existência dos feitiços. Entretanto, havia igualmente espaço para a menção de outros sintomas que não apareciam canonicamente repetidos em todos esses tratados e/ou a ênfase em determinados aspectos mais pontuais da magia malévola. Gomes Ferreira, por exemplo, parecia bem mais preocupado que seus pares em descrever em maiores detalhes as manifestações externas que marcavam os corpos dos enfeitiçados, como inchaços, falta de apetite e perda de peso, além da impotência sexual (o "ligamento"). No manual de Brognolo, por outro lado, encontrei ampla e diferenciada descrição dos sintomas dos feitiços e de outros males produzidos pelas vexações demoníacas, como desequilíbrio dos humores, cegueira, debilidades motoras. Além disso, esse autor - o que não seria de se estranhar, tratando-se de um padre exorcista - e Abreu, que como vimos além de médico era familiar da Inquisição, carregaram bem mais nas tintas para deslindar a intimidade que as feiticeiras teriam com o demônio, fazendo eco mais diretamente à literatura que tratava desse tema em outras partes da Europa.

Nas denúncias recolhidas, principalmente nas devassas eclesiásticas e mesmo pelos agentes do Santo Ofício (pelo menos as que foram objeto de análise em minha amostragem), contra pessoas acusadas de serem feiticeiras, não foi possível encontrar em profusão narrativas das formas com que esses feitiços fustigavam os corpos por eles supostamente atingidos. Entretanto, em alguns desses casos nos chegam descrições mais detalhadas, a oferecer maior lastro para pensar nas formas de conceber os sintomas dos feitiços para além das páginas publicadas por cirurgiões e médicos.

A preta forra Clemência, moradora na freguesia de Antônio Dias, distrito de Vila Rica, era reputada refinada feiticeira, motivo pelo qual já se encontrara presa na cadeia da vila e era acusada de matar com feitiços certa Rita, também forra. Uma vez mais em ação, Clemência era denunciada pelo sapateiro Manoel Gomes por tê-lo enfeitiçado e matado uma de suas escravas. Em sua fala, deparamo-nos com uma rara impressão dos sintomas causados pelas doenças de feitiço narrados por uma suposta vítima:

Entrando por ella [a porta] a dentro a dita denuncia [sic.] acompanhada de huma mulata chamada Francisca por alcunha trinca pulgas foi logo servida a cozinha com algazarra (...) não sabe elle testemunha o que estava a fazer com as mãos, porque ficou logo attonito e sem liberdade para lançar para fora de caza (...) e logo de madrugada veyo huma negra delle testemunha que morava em Antonio Dias e depois de bater a porta entrou a lhe dizer que sonhava toda noite que havia acontecido mall a elle testemunha e por isso vinha ver o que era e adoecendo pouco depois a negra delle testemunha veyo a morrer sem se saber a cauza da enfermidade porque achando-lhe o médico syntomas de várias queixas nunca lhe acertou com remedio para ella e elle testemunha ficou tão pateta por largo tempo não pode continuar com as suas devoções excepto a de Nossa Senhora que nunca a deixou e ainda hoje não logra perfeita saúde o 
que tudo isso aconteceu por haver dito a negra delle testemunha humas rezons [sic.] coma tal clemência. ${ }^{46}$

A preta forra Rita também narra as ações da feiticeira Clemência, acrescentando em sua denúncia mais uma pessoa que teria sofrido em suas mãos. Tratava-se de uma mulata de nome Agostinha que "endoidecera por maleficios que Ihe fizera a dita negra". Os moradores locais, diante dessa ameaça não fizeram por menos e correram com a feiticeira da rua em que residia. Nas denúncias contra Clemência é notória a ênfase na alteração do estado mental das vítimas - nesse caso, expresso nos termos ficar "attonito", "tão pateta" e "endoidecer" - como sintoma dos feitiços, em consonância com a escrita de cirurgiões e médicos como Ferreira e Abreu, que igualmente tributaram esse efeito à ação das bruxas.

Na freguesia de Nossa Senhora do Pilar do Ouro Preto, a preta forra Polônia fora lembrada em quatro denúncias que lançam luz sobre suas ações como feiticeira. Seu principal alvo era um homem livre de trinta e dois anos chamado João Gonçalves, que inclusive comparecera à mesa da devassa para pessoalmente delatar o mal que Polônia teria feito contra ele: "o tinha legado [sic] para não ter acesso com outra mulher". Além de inclinar a vontade sexual de Gonçalves, os feitiços da negra o afetaram de modo a se encontrar "pasmado" e se "esquecer quando falava". ${ }^{47}$

A preta Agostinha Rois, em Mariana, tal qual Polônia, se utiliza de feitiços para inclinar vontades. O alvo do "ligamento" fora o próprio noivo e para tanto a negra usou suas roupas, fazendo várias benzeduras e dando saltos encima "em roda de uma gamela com água repetindo palavras que não entenderam e cozinhou a roupa". ${ }^{48}$

O ligamento como sintoma de feitiço era lembrado de modo recorrente no cenário luso, marcando presença, como vimos, nas páginas escritas pelo cirurgião Gomes Ferreira. Em seu estudo acerca das práticas de feitiçaria, Pedro Paiva sublinha a frequência com que tais expedientes eram usados pelas feiticeiras portuguesas, ${ }^{49}$ realidade que também se mostra nas Minas setecentistas, engendradas por negras escravas e forras. Difícil então não pensar nas possibilidades de trocas e circulações dessas crenças e práticas.

Não obstante, eram mais tipicamente sintomas físicos, como dores, tolhimento, e, no limite, óbitos, que marcariam maior presença nas denúncias contra as(os) feiticeiras(os) nos arraiais auríferos.

Teresa crioula queixou-se ao comissário do Santo Ofício João Rois Cordeiro de ter sido alvo da ação de dois feiticeiros. Um deles, Francisco Cabo-verde, também era escravo de seu senhor e Ihe ofereceu uma comida com feitiços. Previdente, Teresa prontamente descartou o suspeito

46 AEAM. Devassas Eclesiásticas, 1753, f.116-116v. (Grifos nossos).

47 AEAM. Devassas Eclesiásticas, 1734, w12, f.35v; 45; 47v.

48 Portugal. ANTT. Inquisição de Lisboa. Cadernos do Promotor, n.121, f.75.

49 PAIVA, José Pedro. Bruxaria e superstição num país sem "caça às bruxas", p.96ss. 
alimento, dando-os aos porcos. Resultado: "um morreu logo e os outros ficaram tremulos até morrer tudo por arte do demonio". Aqui sublinho, mais uma vez, a ênfase tão comum aos malefícios que levavam a óbito. Entretanto, o outro feiticeiro definido apenas como escravo de nação cabú, descontente com o fato de a crioula ter rechaçado o convite para ter com ele "atos ilícitos", deitou feitiços no seu caminho, "tanto que principiaram a encolher os pés, braços e todos os membros do corpo, ficando entrevada por vários anos", conforme elenca as moléstias resultantes dos feitiços que dessa vez atingiram-na. ${ }^{50}$

A negra mina Agostinha Pinta se enredou por seus feitos numa devassa realizada em Sabará, sendo objeto de lembrança da fala de três denunciantes. O maior alvo da escrava era seu senhor que em função dos feitiços feitos por Agostinha padecia do "peito dores e doenças". ${ }^{51}$ Margarida, que ora era mencionado como parda, ora como preta, na denúncia engendrada pelo licenciado João Pereira Lima, também agia como feiticeira. Certa ocasião, ao dar um abraço numa das escravas do denunciante, esta passou a ficar "tolhida e com muitas dores". Outra escrava, dessa vez de Simião Coelho, foi vítima dos feitiços de Margarida que depois de ter oferecido um ramo de flores para ela cheirar "ficou com várias dores assim [sic.] mover". ${ }^{52}$

Nessas denúncias, novamente é possível salientar a consonância entre as páginas dos tratados médicos aqui analisados e o conteúdo dos casos denunciados (ou da forma com que eles foram escritos pelos padres secretários das devassas eclesiásticas e os agentes da Inquisição), onde as dores e tolhimentos também se fazem presentes entre os sintomas mais recorrentes provocados pelos feitiços. Não seria improvável imaginar que parte desses clérigos pudesse ter contato com o conteúdo dos tratados médicos, além de textos produzidos fundamentalmente por seus pares, como eram os tratados demonológicos e manuais de exorcismo, embora tal argumento não seja em nada conclusivo, posto que carece de bases empíricas mais sólidas..$^{53}$

Assim, uma vez mais, o universo dos feitiços nos apresenta outros horizontes de leitura. Crenças e medos tão assíduos entre aqueles que habitavam as Minas do século XVIII e instigante manancial de possibilidades de olhares para o pesquisador atual.

50 Portugal. ANTT. Inquisição de Lisboa. Cadernos do Promotor, n.129, f.527

51 AEAM. Devassas Eclesiásticas, 1759, f. 7v e 9.

52 AEAM. Devassas Eclesiásticas, 1722-1723, f.79.

53 Em seus estudos sobre a posse de livros e as leituras nas Minas setecentistas, Luiz Carlos Villalta encontrou entre os bens arrolados em inventários de alguns clérigos tratados médicos, o que pode servir para pensar na viabilidade do que fora acima mencionado. Embora, eu reafirme a necessidade de maiores bases empíricas para sustentar o argumento que aqui não é muito mais que uma inferição. VILLALTA, Luiz Carlos. Os clérigos e os livros nas Minas Gerais da segunda metade do século XVIII. Acervo, Rio de Janeiro, v.8 n.1-2, p.37-38, jan./dez. 1995. 


\section{Considerações finais}

Ao descrever no âmbito teórico-conceitual as formas de enquadramento das doenças, Charles Rosemberg nos fornece utilíssima chave de análise. O complexo processo de desnaturalização das enfermidades permite estender nosso campo de visão e perceber elementos mais amplos da vida social e cultural dentro do nosso recorte de estudo, além de articular os discursos e as práticas dos múltiplos agentes sociais em ação, sejam laicos ou religiosos, vinculados à cultura letrada ou aos estratos populares. ${ }^{54}$

Nessa perspectiva, procurei analisar como a crença nos feitiços , concebidos como um dos poderosos agentes causadores de doenças, se mostrava bastante presente também nas Minas Gerais no curso do século XVIII. Sendo de tal modo frequente e amplamente aceita pelos diversos indivíduos que habitavam os arraiais do ouro, além de configurar-se como importante vetor a influenciar as relações entre senhores e escravos, médicos e pacientes, mecanismos de legitimação e perseguição da Igreja no tocante às práticas de cura, entre outros aspectos do cotidiano dessas pessoas.

Contudo, acreditamos ser preciso para nossos estudos relativizar um aspecto específico da construção teórica de Rosemberg que talvez deva ser pensada de forma mais flexível quando levamos em consideração o que o próprio autor qualifica como ferramentas intelectuais disponíveis numa dada época para o enquadramento das doenças. Referimo-nos à ideia do autor de que as doenças devem existir como entidades específicas e, portanto, serem portadoras de um conjunto de sintomas que Ihes são atribuídos como próprios e garantem seu reconhecimento e unicidade. No caso das doenças de feitiço dos habitantes das Minas do século XVIII, talvez a crença no malefício, ou seja, o ato de causar algum tipo de mal mediante o recurso mágico, seja seu sintoma mais típico e recorrente. Além do malefício percebemos nas denúncias e nas páginas dos tratados escritos por médicos e cirurgiões, a exemplo de Luís Gomes Ferreira, uma quantidade infinitamente maior e não necessariamente repetida de modo mais ou menos articulado por todos esses autores de efeitos observados nos casos de pessoas supostamente enfeitiçadas: visões malévolas, impotência sexual, falta de apetite, inchaços entre outros.

Não obstante tal existência mais vaga e ampla de sintomas, a crença na produção de malefício, muitas vezes acompanhada da demonização do recurso ao sobrenatural, enquadrava e fornecia significados à crença no poder das(os) feiticeiras(os) que habitavam as estreitas ruas e vielas dos arraiais auríferos e motivavam formas de sociabilidade absolutamente fantásticas, o que gera fértil matéria e curiosidade investigativa para pesquisas vindouras.

54 Aqui pensadas essas esferas não como dicotômicas ou estanques, mas à luz da consideração de seus intercâmbios e mesclas, dialogando com pesquisas como as de BURKE, Peter. Cultura popular na Idade Moderna. São Paulo: Companhia das Letras, 1989; GRUZINSKI, Serge. O pensamento mestiço. São Paulo: Companhia das Letras, 2001. 